\title{
Selected areas of threats to the security of accounting information system
}

\author{
Anna KUCZYŃSKA-CESARZ *1 \\ ${ }^{1}$ Military University of Technology, Warsaw, Poland
}

\begin{abstract}
The accounting system perceived as a credible and reliable source of information about the economic and financial situation of entities operating in the Polish economy and subjected to the accounting law, operates under the conditions defined by cyberspace. The digitization of almost all stages of the work of financial and accounting units as a result of the implementation of many regulations of national and international law has become the cause of threats to the security of publicly available data characterizing the status of economic entities. The widespread use of computer programs to support accounting systemsfavors in a great extent to the limitation of the security of accounting information, despite the obligatory regulation of this area by applicable law. Although today it is difficult to imagine servicing companies' finances without modern technical solutions, one should always remember about the "dark sides" of digitization, which is an element of cyberspace and its consequences for the development of entities in the future.
\end{abstract}

Keywords: accounting system, financial statements, digitization of accounting, accounting in cyberspace, financial and accounting programs

\section{Introduction}

Pursuant to Polish tax law, the consequence of running a business is the obligation to settle the results of this activity with the tax office. The result of economic activity constituting income is sub-ject to obligatory income tax in accordance with the act on income tax from natural persons or legal persons. In order to determine the tax base for taxpayers subject to Polish balance sheetlaw, the in-dividual company's accounting system, which is a component of the Polish accounting system, is extremely helpful. Based on the entries in the accounting books made during the financial year (as a rule, it corresponds to the tax year), a financial statement is prepared, which is a credible and reliable source of information about the economic and financial situation of the entity. The accounting system is widely recognized as an information system presenting various financial information, which in effect serves mainly the decision-making process, both within the entity and by external users from its environment.

The accounting system of an economic entity can be treated as a special anthropogenic product that allows for the construction of its final product, i.e. financial statements - also a product of hu-man activities, in accordance with the applicable national and international accounting law. The demand for information from the accounting system in the current economic reality increases year by year, especially from such units that are subject to obligatory financial audit (external audit).

It is known that the time requirement, free movement of capital, harmonization and standardiza-tion of applicable law in the world have led to the need to keep accounting systems in a different than traditional, modern form, using widely available financial and accounting programs corre-sponding to the requirements of each type of enterprise. In addition, the accounting system began to function in cyberspace, which was also a requirement of the above-mentioned factors.

The science facing the challenges related to ensuring the security of the created facilities is the engineering of the security of anthropogenic facilities. It concerns the methods of proceeding (in the technical, economic, legal and organizational scope) in the processes of designing, constructing and operating anthropogenic objects aimed at

\footnotetext{
${ }^{*}$ Corresponding author: E-mail address: anna.cesarz@wat.edu.pl (Anna KUCZYŃSKA-CESARZ)
} 
ensuring the safety of these objects by eliminating or re-ducing to an acceptable level threats to humans and the environment of the object or creating condi-tions ensuring effective protection. [1].

Bearing in mind the above, in the current reality the accounting information system is exposed to various threats, sometimes difficult to identify. Security of information from the accounting system is certainly guaranteed by the applicable law and exemplary solutions of security engineering for anthropogenic objects. However, there are areas where the interpretation of legal regulations is am-biguous, and this favors actions that violate the credibility of data included in the financial state-ments. Such areas include, among others, problems related to creative accounting, accounting engi-neering (the issues discussed in the article [6] of the author), digitization of accounting or the functioning of the accounting system in the cyberspace environment. The subject of the last two areas will be the subject of this article.

The aim of the study is to characterise threats to the security of financial information from the accounting system with an indication of their causes and consequences in the areas of digitization of accounting and its functioning in cyberspace [9].

\section{Accounting system as a source of information for the decision-making process}

Among the many definitions of the accounting system included in the literature on the subject for the purposes of this study it is worth quoting one of them, according to which it is perceived as "a comprehensive system for collecting and processing data as well as presenting economic and financial informations regarding: resources, sources of its financing, economic activity, results of economic activity" [20].

Accounting systems are created in order to continuously record changes in assets, sources of its financing, revenues, costs and financial result of all entities subject to the balance sheet law, i.e. the Accounting Act, in a continuous manner, regulated by numerous legal regulations. They are a kind of information system containing numerical data used for the implementation of many goals, both by internal and external decision-makers, and mainly serve the management process and revealing any irregularities that threaten the implementation of set tasks [8].

The accounting system in Poland is created on the basis of the applicable national law (Account-ing Act - Polish balance sheet law - uor) (AA) [21] and international law (International Accounting Standards, International Financial Reporting Standards - functioning as IAS / IFRS and European Union regulations). Entities running a business and subjected to Polish accounting law, obligatorily create their own individual accounting systems, which consequently make up the Polish accounting system.

There are three main reasons for keeping accounting, namely:

- it enables the determination of the basis for calculating the income tax and the final settlement of the achieved results with the tax office, i.e. it serves the needs of tax law,

- is treated as a source of reliable information about the resources of units, sources of financing these resources, revenues, costs and financial result for the purposes of making many important decisions within these units,

- through the financial statements created by accounting, it is possible for entities to contact their external environment and thus to evaluate financial results and the method of managing the as-sets entrusted to management [7].

The final product of the accounting system is the financial statement treated as the primary car-rier of information about the economic and financial standing of the entity to which the statement relates. The structure of the financial statements for various entities has been precisely defined in the annexes to the act. The regulations of the Polish balance sheet law result in the obligation to prepare financial statements according to the layout presented in Table 1.

So how to "read" the financial statement so that the numerical data presented in its individual parts could be interpreted and drawn conclusions for the decision-making process? The answer to this question should be sought by analysing the issues presented in Figures 1 and 2 regarding the information value of component parts of the financial statements.

It should be clearly stated that information from:

- balance sheet - present the characteristics of the assets and sources of its financing, 
Table 1. Elements of the financial statements. Source: own study based on [21]

\begin{tabular}{|c|c|}
\hline Elements of the financial sta & \\
\hline Balance sheet & \\
\hline Profit and Loss Account & Prepared by all entities subject to the balance sheet law \\
\hline $\begin{array}{c}\text { Additional information } \\
\text { - introduction to the report } \\
\text { and additional explanations } \\
\text { and information }\end{array}$ & \\
\hline $\begin{array}{l}\text { Statement } \\
\text { of changes in } \\
\text { equity (fund) }\end{array}$ & $\begin{array}{l}\text { Prepared by entities obliged by law to } \\
\text { financial audit (banks, } \\
\text { insurance and reinsurance companies, credit unions, } \\
\text { entities operating under the provisions on } \\
\text { trading in securities, investment }\end{array}$ \\
\hline $\begin{array}{l}\text { Cash } \\
\text { Flow }\end{array}$ & $\begin{array}{l}\text { other entities which, in the previous financial year, } \\
\text { met at least two of the following conditions: } \\
\text { - average annual employment of at least } 50 \text { people, } \\
\text { - total assets of at least EUR } 2,500,000 \text {, } \\
\text { - net sales revenues of at least EUR } 5,000,000\end{array}$ \\
\hline
\end{tabular}

\section{INFORMATION VALUE OF THE FINANCIAL STATEMENTS}
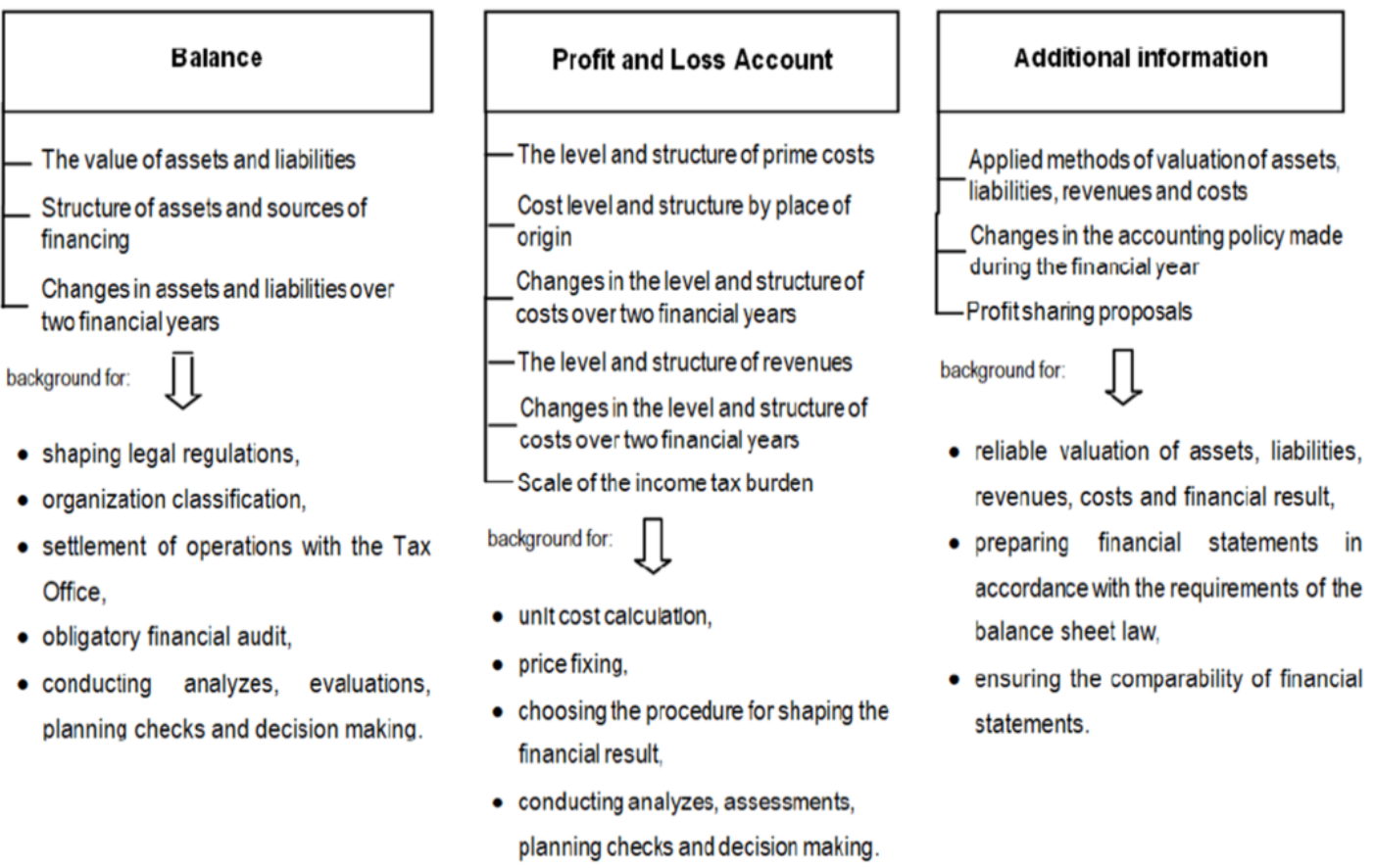

Figure 1. The information value of the basic components of the financial statements[5]

- profit and loss account - allow to learn the procedure of calculating various categories of achieved results (sales result, operating result, gross result and net result),

- additional information - supplementing the data for the presentation of various financial and accounting categories in various parts of the financial statements,

- statements of changes in equity/fund - enable the assessment of sources of creation and reduc-tion of the level 
of various equity capitals in an entity,

- cash flow statement - constitute the basis for the assessment of financial liquidity and indication of the areas of cash generation and areas of its outflow from the entity.
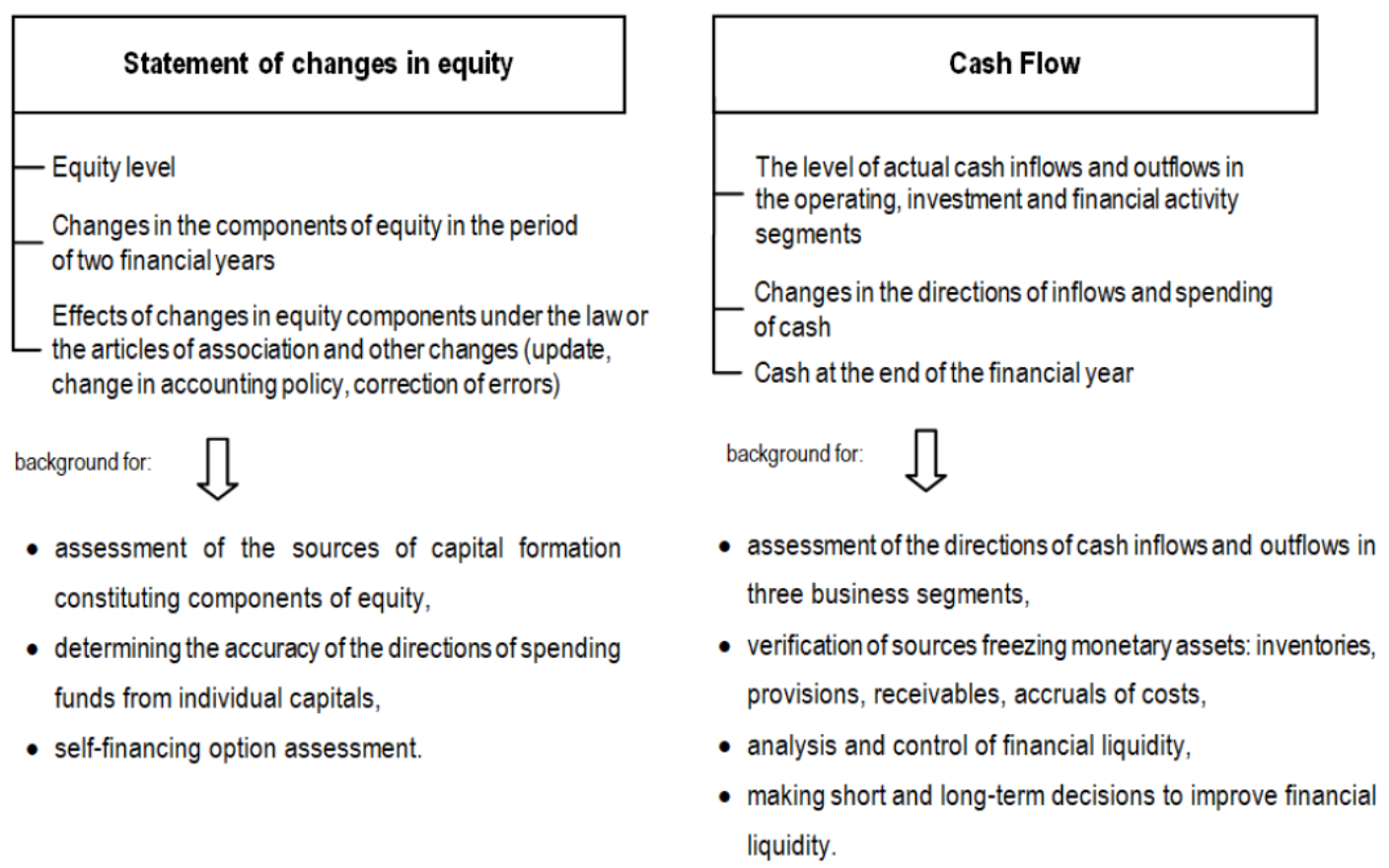

Figure 2. The information value of the remaining (not applicable to all entities) components of the financial statements $[5]$

Based on the numerical datataken from the financial statements, you can perform a financial analysis, as part of a comprehensive analysis of the company's operations. It is carried out for the purpose of assessing the economic and financial situation. The results of such an analysis are impor-tant for the broadly understood decision-making process. The scope of the most frequently per-formed analytical works as part of the analyze of the company's activity is presented in Table 2 .

Table 2. The scope of the analysis of the company's activity. Source: own study based on the researched literature on the subject

\begin{tabular}{|c|c|c|c|c|c|c|}
\hline \multirow[b]{2}{*}{$\begin{array}{l}\text { Identifies the opportunities } \\
\text { and threats for the } \\
\text { functioning of the } \\
\text { enterprise in relation } \\
\text { to the changing environment } \\
\text { and identifies the strengths } \\
\text { and weaknesses } \\
\text { of the enterprise }\end{array}$} & \multicolumn{3}{|c|}{$\begin{array}{c}\text { Analyze of the } \\
\text { enterprise's } \\
\text { environment }\end{array}$} & \multicolumn{2}{|c|}{$\begin{array}{c}\text { Economic } \\
\text { analyze }\end{array}$} & \multirow[b]{2}{*}{$\begin{array}{l}\text { Determines the } \\
\text { economic results } \\
\text { achieved by the } \\
\text { enterprise in the } \\
\text { course of economic } \\
\text { activity }\end{array}$} \\
\hline & 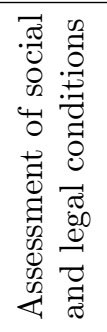 & 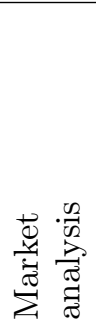 & 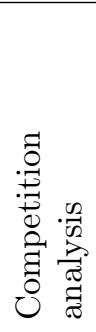 & 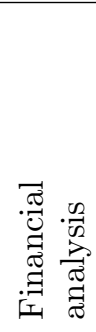 & 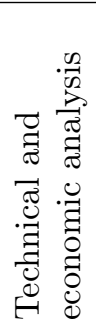 & \\
\hline
\end{tabular}

When assessing the economic and financial condition of an enterprise, one should deal with the area of financial analysis, which, in accordance with Table 3, includes a number of detailed activities enabling, consequently, the formulation of final conclusions for managing the entity and making various long and short-term decisions by the company's external environment.

Within the above-mentioned areas of financial analyzemany instruments (indicators) are used, built on the basis of figures from the financial statements. For each of them, the range of the desired level and the interpretation of 
Inżynieria Bezpieczeństwa Obiektów Antropogenicznych 3 (2021) 37-49

Table 3. Areas of economic analyze in an enterprise. Source: own study based on the researched literature on the subject

\begin{tabular}{|c|c|}
\hline \multicolumn{2}{|l|}{ Economic analyze } \\
\hline Financial analysis & Technical and economic analysis \\
\hline Initial balance sheet analysis & Production analysis \\
\hline Profit and loss account analysis & Analysis of the company's fixed assets \\
\hline Determining and assessing cash flows & Materials management analysis \\
\hline $\begin{array}{l}\text { Analysis of the company's } \\
\text { financial condition in the area of liquidity, } \\
\text { debt, profitability, op-erational efficiency }\end{array}$ & Analysis of technical progress and new launches \\
\hline
\end{tabular}

the obtained result are specified, which greatly facilitates any analyti-cal work. In order to emphasize the importance of information from the reporting accounting sys-tem, Table 4 presents, for example, commonly used procedures for determining indicators from the group of the so-called five golden rules of financing, so important in the assessment of financial liquidity and solvency not only for company managers, but also for potential investors and other entities from the external environment. The numerical data to determine the indicators are mainly taken from the balance sheet, and the interpretation of the results obtained in a specific unit follows the formula for calculating the indicator presented in the table.

Table 4. Five golden rules of financing [10]

\begin{tabular}{|c|c|}
\hline Indicator & Formula to calculate the indicator \\
\hline The golden balance rule (I degree of coverage) & $\frac{\text { equity }}{\text { fixed assets }} \geq 1$ \\
\hline Golden banking rule (II degree of coverage) & $\frac{\text { fixedcapital }}{\text { fixed assets }} \geq 1$ \\
\hline III degree of coverage & $\frac{\text { fixedcapital }}{\text { fixed assets }+ \text { long-term part of current assets }} \geq 1$ \\
\hline Golden rule of funding & $\frac{\text { equity }}{\text { total liabilities }} \geq 1$ \\
\hline Net working capital & Net working capital $>0$ \\
\hline
\end{tabular}

Reliability and credibility of the accounting information system, as already mentioned, is con-firmed by an external audit (the audit report contains the statutory auditor's information on the con-ducted audit), but the issues in this area, due to its complexity, are not considered in this article.

\section{Cyberspace and the accounting system}

The final shape of the accounting system in Poland was influenced by the process of harmoniza-tion and standardization of accounting, which resulted mainly from the need to unify the accounting principles in the area of creating, maintaining, using and interpreting data from information resources of accounting systems in the European Union (EU) countries. The course of these processes was regulated by international balance sheet law (especially by IAS / IFRS) as well as by numerous EU directives. Important for the digitization of accounting processes was Directive 2012/17 / EU of the European Parliament and of the Council of June 13, 2012 on the integration of central, commercial and company registers and Directive 2017/1132 / EU of the European Parliament and of the Council of June 14, 2017. with regard to the regulations on the system of interconnection of registers, which did not introduce new regulations, but was intended to repeal the existing legal acts. As a consequence, they were codified and unified in one document (the problem also concerns earlier legal acts, namely Council Directive 89/666 / EEC and Directive 2005/56 / EC of the European Parliament and of the Council and 2009/101 / EC with regard to the integration of central registers, registers commercial and company registers). This directive is referred to as the BRIS Directive 
(Business Registers Interconnection System), i.e. the system of integration of EU business registers, thanks to which you can have access to detailed information about companies and their branches registered in EU countries.

The implementation of the provisions of the aforementioned directive in the Polish economy was manifested, inter alia, in the obligation to:

1. providing information from accounting books by business entities to tax authorities in the form of a Standard Audit File (JPK, eng. SAF-T),

2. submitting e-applications to the National Court Register (KRS),

3. integration of the National Court Register with the BRIS register integration system,

4. submission of financial statements in electronic form in appropriate data formats,

5. providing full data about the entity on the Internet.

All the above-mentioned rules of conduct are directly related to the exchange of information on the scale of our economy and on a global scale, and they have their place in the digitization process identified with cyberspace.Cyberspace (one of many literary definitions) can be defined as a com-prehensive, automatic complex network, detached from the real world, built with the use of ICT infrastructure, in which human functioning becomes possible, and the information generated in it is the basis of existence and becomes a good of the highest quality [18].

It is also worth citing the JPK (SAF-T) definition formulated by the Organization for Economic Cooperation and Development (OECD), according to which it is a set of data created from IT sys-tems of economic entities (direct data export), containing information on economic operations for any selected period, and having a layout and format (XML ) which enables its easy processing [12].

It should be emphasized that JPK is used to report data for VAT purposes and currently all eco-nomic entities are obliged to create it.

A separate problem, extremely important in creating individual accounting systems operating in the cyberspace environment, is the use in current economic practice of financial and accounting programs available on the market, which are extremely helpful in creating financial information resources used in the implementation of the imposed obligatory requirements of EU directives.

Standard Audit File for Tax (JPK) was introduced in art. 193a, par. 1 of the Tax Ordinance (new provisions of the Tax Ordinance entered into force on 01/07/2016), according to which, in the case of keeping tax books using computer programs, the tax authority may request that all or part of these books and accounting documents be transferred by means of electronic communication or via IT data carriers, in electronic form corresponding to the logical structure, indicating the type of tax books and the period to which they relate. These activities oblige units to ensure security and reli-ability as well as protection against unauthorized access.

Currently JPK has been divided in accordance with the applicable law into two types:

- JPK V7M - for entrepreneurs settling VAT on a monthly basis,

- JPK V7K - for entrepreneurs settling VAT on a quarterly basis.

In addition to the currently applicable new JPK VT structure, the applicable law allowed for the use of additional structures whose task is to improve the work of control bodies. The other JPK structures are:

- JPK PKPIR - refers to entrepreneurs keeping a tax book of revenues and expenses,

- JPK EWP - applies to entrepreneurs keeping a record of revenues- lump sum taxation on re-corded revenues,

- JPK KR - intended for entrepreneurs keeping records on complete books of accounts,

- JPK MAG - includes entrepreneurs with warehouse management,

- JPK FA - applies to all entrepreneurs issuing invoices,

- JPK WB - which applies to bank accounts used as part of running a business,

- JPK FA RR. - applies to entrepreneurs issuing VAT RR invoices.

Structures for micro-entrepreneurs, i.e. JPK FA, JPK PKPIR or JPK EWP and JPK WB, are subject to verification during e-control only at the request of tax authorities. The obligation to trans-fer the remaining structures 
was introduced for micro, small and medium-sized enterprises from July 1, 2018. On the other hand, the JPK FA RR structure entered into force on September 1, 2019.

JPK V7 files - in force from October 2020 (JPK VAT in force until September 2020) are pro-vided only in electronic form, using the platform provided by the Ministry of Finance or an online accounting program. Currently, taxpayers send JPK using: an electronic signature, a signature via a trusted profile by logging into the ePUAP platform or the amount of income. After sending the file, generate the UPO (Official Confirmation of Receipt), which confirms the correct shipment of the file to the tax authorities.

Submitting e-applications to the National Court Register is another area of electronic transmission of information (introduced in the Polish economy with effect from 01/04/2016). As in the case of JPK, mainly for security purposes, they are signed electronically (confirmed with the ePUAP trust profile, a secure e-signature, electronic signature or personal signature in the case of having an e-ID card). It should be clearly emphasized that the obligation to submit all applications to the register of entrepreneurs of the National Court Register and documents constituting the basis for entry into the register by electronic means is regulated in detail in the Act amending the Act on the National Court Register and certain other acts of January 26, 2018. Journal of 2018, item 398 with changes.

The new rules apply to the submission of financial statements to the National Court Register. Taking into account the regulations of the Polish balance sheet law (uor), entities entered in the reg-ister of entrepreneurs are obliged to submit them to the court within 15 days from the date of ap-proval of the financial statements (Article 69 (1)). Certain attachments are submitted along with the report to the court, including a resolution on approving the financial statements, a report on the ac-tivities of an entity or a statutory auditor's report on the audit. These documents were submitted to the court in hard copy along with the application in the form of an official form.

Currently, as a result of an amendment to the applicable law, the submission of documents speci-fied in Art. 69 of the SAA is made by notification via the ICT system (this provision entered into force as early as March 15, 2018 and is the first stage of the process of electronising the registration procedure).The provisions on the principles of preparing financial statements have also been changed in the uor (AA). As a result of the changes, the financial statements must be prepared in electronic form and bear a qualified electronic signature or a signature confirmed by the trusted ePUAP profile (Article 45 (11) of the Act). With regard to entities entered in the Register of Entrepreneurs of the National Court Register, an additional requirement has been introduced to prepare financial statements in a logical structure and format available in the Public Information Bulletin on the website of the office servicing the minister responsible for public finances. The obligation to prepare financial statements in an appropriate structure will also apply to entities that prepare financial statements in accordance with the International Accounting Standards, provided that the appro-priate logical structure and format for such statements is made available by the Minister of Fi-nance.Similar requirements will also apply to the principles of preparing consolidated financial statements. Moreover, it is worth mentioning that based on Art. 70 paragraph. 2 of the Act, the fi-nancial statements of entities conducting business activities subject to Polish accounting law are published in the Court and Economic Monitor (MSiG), and the public finance sector units in the Public Information Bulletin (BIP), which is directly related to access to data from accounting in-formation systems.

\section{Digitization of accounting - benefits and threats}

Digitization can be defined as "activities using digital tools aimed at increasing productivity through the introduction of innovative products, process optimization and effective use of human capital" [2]. Thus, digitization enables the development of new services, and also gives the possibil-ity of more efficient use of resources, such as: technical resources, human capital, and information.

In the current economic reality, digitization has found its reflection in the creation of "modern" accounting systems, which is largely due to the use of computer software commonly used to handle accounting books. Significant changes caused by the digitization of accounting are presented in Figure 3.

Bearing in mind the above, it can be said that "digitization as a determinant of changes in accounting has contributed to the emergence of new scientific directions, such as: internet accounting, cloud accounting or electronic accounting. There are opportunities for issuing e-invoices, e-transfers, e-declarations, creating virtual accounts and placing electronic signatures on documents. An important aspect is to assist accountants in creating IT systems for its better functioning and to support managers who analyze data in order to make appropriate decisions " [22].

The changes caused by the digitization of the accounting system can be viewed through the prism of the benefits and threats presented in Figure 4. 


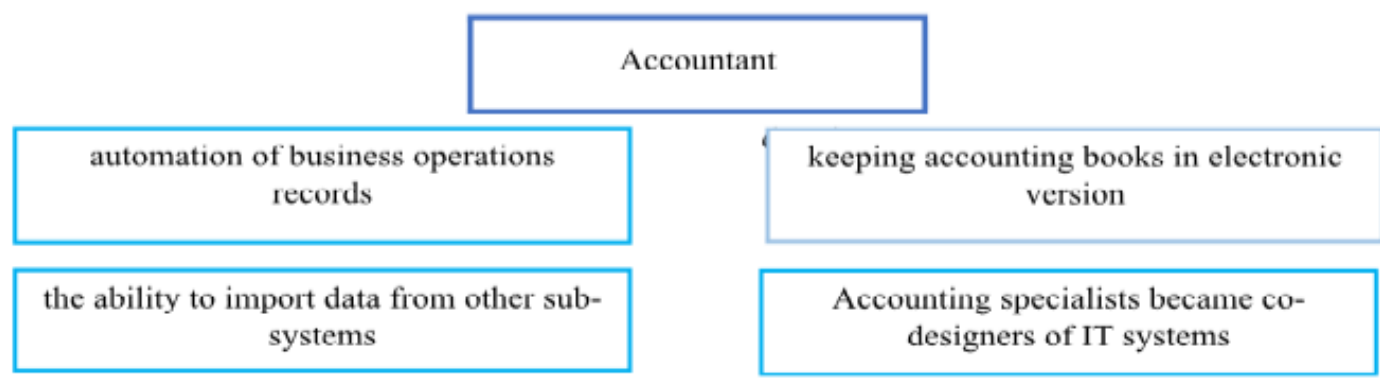

Figure 3. Changes in accounting due to digitization [2]

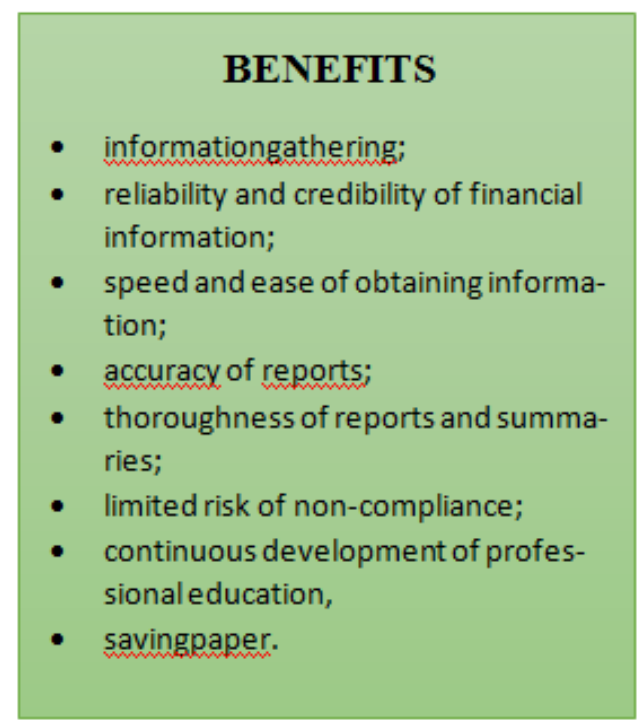

\section{THREATS}

- time-consuming adjustment and implementation of the system;

- development constraint - obsoletetechnologies;

- inadequatesystemiccooperation;

- regularity and chronology of data records;

- ease of making a mistake when entering data;

- the cost of introducing changes to systems and registrations;

- unpreparedness for newthreats;

- selection of qualifiedstaff.

Figure 4. Benefits and threats of introducing digitization into accounting [14]

Information systems used in enterprises are designed to gather information. The place where in-formation can be collected is almost limitless, which gives them a significant advantage over an industry specialist. This also translates directly into the reliability and credibility of financial infor-mation as well as the speed and ease of obtaining information. IT systems supporting accounting also mean the accuracy and detail of reports and summaries with a very limited risk of non-compliance. On the other hand, we have all the disadvantages associated with computerization - time-consuming adaptation and implementation of the system, cyclical "aging" of technology and costs related to introducing changes to the systems. Online activity is also a potential threat to our data. An important role in the digitization of accounting is played by qualified employees who have to implement the newly introduced systems and their changes. System users must properly prepare as part of their own professional development, should take part in self-learning processes in order to work effectively and be prepared for the changes resulting from the ongoing digitization.

The results of research conducted by KPMG among German companies in 2017, mainly among employees such as CFOs (Chief Financial Officers), Chief Accountants and other people dealing with accounting (the surveyed group is 146 people), can be used to assess the state of digital solu-tions in accounting [3].

In the case of eleven selected digitization solutions presented below, respondents were asked to indicate whether they have already been implemented in their companies or whether they will be introduced in the near future. Based on the responses, companies were assigned the level of digiti-zation.

The following range of digital solutions was analyzed: 
1. Accounting without documents - specific documents digitized (eg invoices) or the entire docu-mentation is already digitized.

2. Interfaces to (external) systems - received invoices and other files of partners (eg suppliers, banks) are in the forms supported by IT systems.

3. Data quality management - the quality and accuracy of data is checked at least once a year.

4. Process automation - use the latest digital capabilities to automate routine processes.

5. Real-time reporting - use of innovative technologies such as fast databases for quick analysis.

6. System homogeneity - the main accounting systems are largely homogeneous

7. Integrated consolidation system - the company has a consolidation system that can directly ac-cess data from the corporate section.

8. Creating transparency - the systems used enable analyzes from very wide ranges to detailed re-sults.

9. Big Data analyzes - we actively use knowledge in the area of big data in the accounting system.

10. Tools for visualization - active use of tools for digital visualization of the results of data ana-lyzes in graphical form with varying degrees of detail depending on the needs.

11. Cloud computing - most of the files have been moved to cloud solutions.

As a result of the research carried out, after the creation of the maturity level model for the dig-itization of accounting, it was found that in the analyzed period this process was carried out at an average level in the majority of companies. 66 percent of all surveyed companies were in the me-dium maturity range, both in the area of already implemented digital solutions and in the area of managing digitization activities. Only 15 percent of all companies could be characterized as pioneers of digital technology. In these companies, numerous digital solutions have been implemented in accounting, and the digitization process is carried out and managed according to a transparent plan.

In the Polish economy, there are attempts to implement in practice the knowledge map model, treated as a tool enabling the processing of information into knowledge understood as an organized set of information with the rules for its interpretation. This is of particular importance for accounting treated as a specific information system containing numerical data on the entity's financial position. "Properly processed data can become information, and processed and structured information can be transformed into knowledge, which is closely related to the processes specific to a given enterprise" [11].

\section{$5 \quad$ Accounting and financial and accounting computer systems}

The condition for the proper functioning of the enterprise and its management is access to spe-cialist knowledge. Satisfying the needs related to the necessary knowledge is possible thanks to an effective information system. Currently, the most commonly used systems are integrated systems, which are used for comprehensive service of all areas of the enterprise.

Characteristic features of integrated systems are [4]:

- integration of data and processes taking place both in the system and in its environment;

- flexibility, which allows to adjust the applied hardware and software solution during installa-tion and start-up of the system, and also enables it to be adapted to the changing conditions in the organization and the influence of the environment;

- openness, i.e. the possibility of expanding the system with new modules,

- IT support for decision-making processes;

- technological progress ensuring compliance with current software and hardware standards, as well as enabling free data migration;

- compliance with applicable regulations.

The accounting system, perceived as a special information system, is currently run in the economy on the basis of financial and accounting systems that differ from each other in terms of the target group of recipients and the 
reports they prepare. The minimum requirements for computer systems supporting the company's accounting are set out in the Accounting Act. However, no procedures have been defined to enable the determination of whether the requirements are met in the currently used IT systems. It is a good practice for producers of IT software used for accounting to obtain the recommendations of the Accountants Association in Poland, which is presented in the Table 5.

Table 5. List of financial and accounting programs recommended by the Accountants Association in Poland [19]

\begin{tabular}{|c|c|c|c|}
\hline No. & $\begin{array}{c}\text { Name of the } \\
\text { software product }\end{array}$ & $\begin{array}{l}\text { Date of the } \\
\text { recommendation }\end{array}$ & $\begin{array}{l}\text { The company applying } \\
\text { for the recommendation }\end{array}$ \\
\hline 29 & IFS Applications w wersji 10 & 21.08.2019 & $\begin{array}{l}\text { IFS Industrial and Financial } \\
\text { Systems Poland Spółka z o.o. }\end{array}$ \\
\hline 28 & IFS Applications w wersji 9 & 18.01.2017 & $\begin{array}{l}\text { IFS Industrial and Financial Systems } \\
\text { Poland Sp. z o.o. z siedzibą w Warszawie }\end{array}$ \\
\hline 27 & Impuls EVO & 07.10 .2015 & $\begin{array}{l}\text { Biuro Projektowania Systemów } \\
\text { Cyfrowych S.A. }\end{array}$ \\
\hline 26 & IFS Applications w wersji 8 & 08.10 .2013 & $\begin{array}{l}\text { Industrial and Financial } \\
\text { Systems Poland Sp. z o.o. Warszawa }\end{array}$ \\
\hline 25 & $\begin{array}{l}\text { Papirus SQL dla modułów: } \\
\text { Finansowo-Ksiegowy w wersji } \\
2.07 .10 .00 \text { Rejestry Faktur } \\
\text { w wersji } 1.05 .46 .20\end{array}$ & 19.03.2013 & SOFHARD S.A. Płock \\
\hline 24 & IFS Applications w wersji 7.5 & 20.04.2009 & $\begin{array}{l}\text { Industrialan and Financial } \\
\text { Sytems Poland Sp. z o.o. Warszawa }\end{array}$ \\
\hline 23 & $\begin{array}{l}\text { Oracle e-Business Suite, wersja } \\
12\end{array}$ & 23.09 .2008 & Oracle Polska Sp. z o.o. Warszawa \\
\hline 22 & IMPULS, wersja 5 & 17.12 .2007 & BPSC S.A. Chorzów \\
\hline 21 & $\begin{array}{l}\text { SIMPLE.ERP w zakresie } \\
\text { modułu Majątek Trwały } \\
\text { w wersji 5.00a }\end{array}$ & 04.09.2007 & SIMPLE S.A. Warszawa \\
\hline 20 & Euro Bank Net w wersji e06 & 16.01 .2007 & SoftNet Sp. z o. o. Kraków \\
\hline 19 & $\begin{array}{l}\text { SIMPLE. ERP, moduł } \\
\text { Finanse i Księgowość } \\
\text { w wersji } 5.0\end{array}$ & 16.01.2007 & SIMPLE. S.A Warszawa \\
\hline 18 & $\begin{array}{l}\text { RAMZES Amortyzacja, wersja } \\
05.28 .06\end{array}$ & 22.11 .2005 & Ramzes Sp. z o. o. Warszawa \\
\hline 17 & CDN OPT!MA , wersja 8.6. & 23.08 .2005 & COMARCH SA Kraków \\
\hline 16 & SAP Business One, wersja 7.6 & 15.02 .2005 & SAP Polska Sp. z o. o. W-wa \\
\hline 15 & $\begin{array}{l}\text { WF-FaKir, wersja } 6.10 .5 \\
\text { i WF-bEST, wersja } 6.10 .3\end{array}$ & 15.02.2005 & WA-PRO Sp. z o.o. \\
\hline 14 & $\begin{array}{l}\text { RAMZES- Księgi Handlowe, } \\
\text { wersja 01.25.01 }\end{array}$ & 16.11.2004 & Ramzes Sp. z o. o. Warszawa \\
\hline 13 & SAP Business One, wersja 7.5 & 31.08 .2004 & SAP Polska Sp. z o. o. W-wa \\
\hline 12 & $\begin{array}{l}\text { „System Zarządzania Firmą } \\
\text { DIGITLAND ENTERPRISE”, } \\
\text { moduł Finanse i Księgowość, } \\
\text { wersja } 15.05\end{array}$ & 18.11.2003 & PHU „DIGIT-LAND W. Wierzba Kraków \\
\hline 11 & $\begin{array}{l}\text { „Finanse i Księgowość- forte" } \\
\text {, wersja } 5.00\end{array}$ & 04.02 .2003 & MATRIX Pl. Warszawa \\
\hline 10 & SKOP-FK, wersja 6.1. & 14.05 .2002 & $\begin{array}{l}\text { Bytomska Spółka Informatyczna } \\
\text { COIG } 4 \text { Sp. z o. o. Bytom }\end{array}$ \\
\hline 9 & $\begin{array}{l}\text { System Ekonomiczno } \\
\text {-Finansowy } \\
\text { Pro-FIN", wersja } 3.30\end{array}$ & 10.09.2001 & Pro-Test S.A. Warszawa \\
\hline 8 & IFS FINANSE & 10.09 .2001 & Indutrial and Financial System \\
\hline
\end{tabular}


Table 5. List of financial and accounting programs recommended by the Accountants Association in Poland [19]

\begin{tabular}{|c|c|c|c|}
\hline No. & $\begin{array}{c}\text { Name of the } \\
\text { software product }\end{array}$ & $\begin{array}{l}\text { Date of the } \\
\text { recommendation }\end{array}$ & $\begin{array}{l}\text { The company applying } \\
\text { for the recommendation }\end{array}$ \\
\hline 7 & $\begin{array}{l}\text { SAP R/3- moduły FI } \\
\text { (GL, AP, AR, AA, BL) } \\
+ \text { CO (OM-CEL, OM-CCA, } \\
\text { OM-OPA, OM-IS, PC-OBJ) } \\
\text { wersja 4.6C }\end{array}$ & 20.07.2001 & SAP Polska Sp. z o. o. W-wa \\
\hline 6 & „NOVUM BANK”, wersja 4GL & 19.12.2000 & $\begin{array}{l}\text { Zakład Usług Informatycznych } \\
\text { NOVUM Sp. z o. o. w Łomży }\end{array}$ \\
\hline 5 & $\begin{array}{l}\text { IMPULS-BPSC, podsystem } \\
\text { FINANSE-KSIĘGOWOŚĆ } \\
\text {-KOSZTY, } \\
\text { wersja } 4.2 .\end{array}$ & 19.12.2000 & $\begin{array}{l}\text { Biuro Projektowania } \\
\text { Systemów Cyfrowych } \\
\text { BPSC Katowice }\end{array}$ \\
\hline 4 & ADAPTIX/FK, wersja 108A & 19.09.2000 & „MaWi” Ag. Informat.. Kraków \\
\hline 3 & $\begin{array}{l}\text { FIKS system } \\
\text { finansowo-księowy, } \\
\text { wersja } 8.14\end{array}$ & 14.09.1998 & Makcrosoft S.A. Warszawa \\
\hline 2 & $\begin{array}{l}\text { SYSTEM FINANSOWO } \\
\text {-KSIECGOWY } \\
\text { FKX WERSJA } 7.24 .026 .\end{array}$ & 22.06 .1998 & $\begin{array}{l}\text { Prokom Softwore } \\
\text { Sp. z o. o. Gdynia }\end{array}$ \\
\hline 1 & SIMPLE-FK, wersja 4.50 (a) & 04.03 .1996 & SIMPLE \\
\hline
\end{tabular}

The leading supplier of financial and accounting systems in Poland for small and medium-sized enterprises is Sage. Sage purchased a software called Symphony (which was created in the early 1990s) from MATRIX. Since then, the software has been expanded and includes such modules as: Sage Symfonia Finance and Accounting, Sage Symfonia Start 2.0, Mała Księgowość, Sage Symfo-nia 2.0 or Fixed Assets.

The module called Sage Symfonia Finanse i Księgowość is addressed to companies with full ac-counting. It enables the recording of all key business operations. The main advantages of the system include: simple adjustment of the program to the company's needs, data security, simple operation, ongoing control of assets and liabilities, summaries, reports and useful analytical charts [16]. Symphony is useful in the implementation of all basic accounting operations: from setting up accounts and accounting documentation, through automatic closing balance, full settlements, and ending with the creation of status reports, statements and reports.

Comarch is another leader in providing accounting systems. The company offers 4 types of pro-grams tailored to the needs of enterprises. These are programs adapted for trade and service compa-nies and commercial networks, for small and medium-sized enterprises of a production, trade and service nature, for small and medium-sized enterprises and accounting offices, as well as a mobile program for small companies.

Sputnik Software has created the SJO BeSTi @ [17] System at the request of the Ministry of Fi-nance. The program aims to improve the financial management of territorial units. It is useful for organizational units of territorial units to perform tasks that include:

- preparation of individual reports in monthly and quarterly reporting periods;

- preparation of unit balance sheets of budgetary units, local government budgetary enterprises, summary balance including data resulting from the balances of local government budgetary units and local government budget departments, LTU balance and the consolidated balance;

- budget planning from the stage of preparing the draft budget to all modifications;

- data exchange between organizational units and a territorial unit.

Rewizor GT is also one of the professional financial and accounting systems for small and me-dium-sized companies. The program was created on the basis of the Accounting Act and is adapted to the requirements of the European Union. It is intended for both business accountants and ac-counting offices. The latest version of the program is Rewizornexo PRO. It enables, among others using multi-level card accounts, creating your own reports and forms, own description of economic events, e.g. additional transactions with VAT or spreading liabilities into installments 
or booking them on your own types. Rewizornexo PRO is part of InsERTnexo PRO - an integrated package also including: Subiektnexo PRO - sales and warehouse management system, Rachmistrznexo PRO software for simplified accounting, Gratyfikantnexo PRO - HR and payroll system and Gestor nexo PRO - a system for customer relationship management [15].

You can also extract the RAKSSQL system containing a module called the KsiegaHandlowa, which is intended for the preparation of full accounting of enterprises: domestic, private, coopera-tive, non-profit organizations and funds. It enables the implementation of various types of account-ing operations, from creating a chart of accounts and simple accounting of documents, through set-tlements and settlements, to automatic creation of a full balance sheet table and calculation of prof-its and losses, various types of declarations, as well as statements and reports. The module works alone or in combination with other modules of the RAKSSQL system, with which it forms a whole. The system works with the banking settlement systems Home Banking, generates applications and settlement documents for ZUS [13].

\section{Conclusions}

The management of enterprises operating in the Polish economy is based on information con-nected with many areas of their activity. Only selected, up-to-date and relevant information is proc-essed for various needs, especially the needs of the decision-making process. for potential investors. The use of professional financial and accounting programs allows its recipients to use numerous instruments and functions useful for assessing the company's condition.

It is well known that the comprehensive use of the Internet and modern technologies results in the design of faster, complex and integrated IT systems necessary for accounting. Enterprises, trying to be innovative on the market, constantly introduce new software, which not only accelerates and facilitates the management of enterprises, but also contributes to significant savings and increased competitiveness on the market. The above process allows for the formulation of the assumption that the market of IT financial and accounting systems will develop in the future and has a great potential for growth. However, it should be borne in mind that the benefits of the digitization of the accounting system in many areas of its operation, due to the conditions determined by cyberspace, face barriers that threaten information security. The consequences of these threats are certainly significant and translating them into the developed effects is one of the complex issues that may be considered in another study in this thematic area.

\section{References}

1. Baryłka, A. Podstawy inżynierii bezpieczeństwa obiektów antropogenicznych. Inżynieria Bezpieczeństwa Obiektów Antropogenicznych 1, 14 (2015).

2. Cyfrowa Polska. Szansa na technologiczny skok do globalnej pierwszej ligi gospodarczej, raport opracowany przez McKinseya and Company Forbes Polska. 2016. https://www.mckinsey.com/pl/our--insights.

3. Digitalization in accounting. Study of the Status Quo in German Companies. KPMG 2017, Re-trieved from https://assets.kpmg/content/dam/kpmg/de/pdf/Themen/2017/ igitalisation-in-accounting-en-2017-KPMG.pdf

4. Grodziński, R. Architektura zintegrowanego systemu informatycznego zarzadzania. Ogólne informacje o strukturze ZSIZ (ed Bytniewski, A.) 12-13 (Wydawnictwo Akademii Ekonomicznej im. Oskara Langego, Wrocław, 2005).

5. Kuczyńska Cesarz, A. Rachunkowość kreatywna a bezpieczeństwo informacji zawartych w sprawozdaniu finansowym. Nowoczesne System Zarzadzania 13, 115 (1 2018).

6. Kuczyńska Cesarz, A. Rachunkowość kreatywna a bezpieczeństwo informacji zawartych w sprawozdaniu finansowym. Nowoczesne System Zarzadzania 4, 1-16 (2019).

7. Kuczyńska Cesarz, A. System rachunkowości jednostki budżetowej a system rachunkowości podmiotu gospodarczego. Nowoczesne systemy Zarzadzania 14, 155 (1 2019).

8. Kuczyńska Cesarz, A. \& Sczerbak, M. Narzędzia rachunkowości podstawa stabilności sektora finansów publicznych 13 (Difin, Warszawa).

9. Kuczyńska Cesarza, A. Rachunkowość kreatywna a bezpieczeństwo informacji zawartych w sprawozdaniu finansowym. Nowoczesne System Zarzadzania 13, 114 (1 2018).

10. Lachowski, W. Prezentacja:Wykorzystanie procedur analitycznych w procesie badania sprawozdań finansowych, Centrum Edukacji PIBR, 67 Warszawa, 2019.

11. Obolewicz, J., Baryłka, A., Szczerbak, M. \& Kuczyńska Cesarz, A. The knowledge map as a management tool for the perception of occupational health and safety for construction facultiles students. Inżynieria Bezpieczeństwa Obiektów Antropogenicznych 1, 16-17 (2021).

12. Oleśniewicz, J. JPK - wstęp do cyfryzacji rachunkowości i rewizji finansowej. Rachunkowość 8, 18 (2016). 
13. RAKSSQL 2021. https://www.raks.pl.

14. Raport o cyfryzacji kraju, Ministerstwo cyfryzacji, 20-27 2020.

15. Rewizor nexo PRO 2021. https : //www . insert.com.pl/programy_dla_firm/ksiegowosc_i_finanse/ rewizor_nexo_pro/opis.html.

16. Sage 2021. http : / / www . sage . com . pl / produkty / obszar - finansowo-ksiegowy / ksiegowosc/sage symfoniafinanse-i-ksiegowosc/szczegoly\#link0.

17. SJO Besti@, DokumentacjaUzytkownika.pdf 2021. https ://serwis.sputnik.pl : 6884/pliki/instalki/ Bestia/SJO.

18. Spychała, T. rachunkowości a cyberprzestrzeń w społeczeństwie sieci. Zeszyty Naukowe PTE w Zielonej Górze, 112 (11 2019).

19. Stowarzyszenie Ksiegowych w Polsce 2021. https://skwp.pl/stowarzyszenie/uslugi/, .

20. Szczypa, P. Zasady rachunkowości. Teoria, przykłady, zadania, wyd. V zmienione 9 (CeDeWu).

21. Ustawa z dnia 29 września 1994 r. o rachunkowości, Dz. U. z 2019 r. poz. 351 ze zm.

22. Zuchewicz, J. Współczesne determinanty rozwoju rachunkowości. Naukowe Uniwersytetu Ekonomicznego we Wrocławiu 195 (2015). 